\title{
Economic Analysis of Broiler Production in Lagos State Poultry Estate, Nigeria
}

\author{
Omolayo Joshua Olorunwa \\ Department of Agricultural Economics and Extension, Landmark University, Omu-Aran, Nigeria
}

\section{Email address:}

phocusomolayo@yahoo.com

\section{To cite this article:}

Omolayo Joshua Olorunwa. Economic Analysis of Broiler Production in Lagos State Poultry Estate, Nigeria. Journal of Investment and Management. Vol. 7, No. 1, 2018, pp. 35-44. doi: 10.11648/j.jim.20180701.15

Received: February 15, 2018; Accepted: March 16, 2018; Published: April 9, 2018

\begin{abstract}
The study on the economic analysis of broiler production was carried out in Lagos State Ministry of Agriculture and Cooperative' Poultry Estates, Nigeria. A two-stage sampling technique was employed for the selection of 100 out of 193 broiler farmers. The research findings revealed a male dominance (73\%) in broiler production and an average age of 45 years within the range of 40 and 49 . Also, majority of the broiler farmers $(90 \%)$ were fully involved in broiler production, married $(80 \%)$ and literate $(90 \%)$, with an average farming experience of less than 9 years $(81 \%)$, average household size of 4 persons (78\%) and an average flock size of about 400 birds. It was found that over $80 \%$ of the cost of production was on the variable inputs while feeds constituted the highest percentage of the variable costs. This accounted for $54.86 \%$ of variable costs and $44.8 \%$ of the total costs. The result of the findings showed that a single broiler bird nurtured to maturity had a total cost of $\$ 1509.8$ made up of $\$ 274.2$ as fixed cost and $\$ 1235.6$ as variable cost. The gross revenue per bird was $\$ 2169.99$. The Net profit of $\$ 660.11$ per bird was estimated and this gives a net margin-to-cost ratio of 0.44 which implies that a investment in broiler production, all things being equal, would yield 44kobo in return. This indicates that the broiler in poultry estate were profitable. The maximum likelihood estimate of the stochastic frontier production function reveals that quantity of feeds and flock size were highly significant at $5 \%$ and $1 \%$ risk level respectively. Educational level of farmers and years of experience were the factors positively influencing the technical efficiency of broiler production in the study area. The estimated technical efficiency of the broiler farmers ranged from $57 \%$ to $96 \%$ with a mean technical efficiency of $74 \%$. Disease outbreak, inadequate finance and high cost of feed were the serious problems faced by the farmers. It was therefore recommended that broiler farmers should increase their flock size, develop the skills of record keeping and feed formulation to reduce feed cost.
\end{abstract}

Keywords: Broiler Production, Profitability, Technical Efficiency, Cobb-Douglas Stochastic Production Frontier Function, Lagos State, Poultry Estate, Nigeria

\section{Introduction}

Agriculture remains the pillar of the Nigerian economy for growth, development, poverty alleviation, contribution to GDP, employment and income generation [37]. It is very important amongst the most vital segments of the economy; it utilizes more than $60 \%$ of the working populace and contributes with livestock, forestry, and fisheries and in terms of real Gross Domestic Product (GDP); agriculture contributes around 42\% between 2003 - 2007 and the sub sector became averagely $7.4 \%$ over the same period [17]. Livestock production constitutes a critical and basic part of the agricultural economy of Nigeria, a contribution that goes beyond direct food production however incorporates the generation of employment, source of income to farmers, development of a country's economy, source of vocation to farmers and other multipurpose uses. Poultry is a noteworthy sub sector in the livestock industry, which contains chickens, turkeys, ducks, quails, peafowl, guinea fowls etc. however chicken alone constitutes as much as $95 \%$ of all poultry kept on the planet [26].

Poultry production is unique in that it offers the highest turnover rate and the quickest returns to investment outlay in the livestock enterprises [38]. The industry has been described as the fastest means of solving the problem of protein deficiency in Nigeria [8]. Poultry production is special; it has the highest feed conversion rates and produces the least expensive and best sources of animal protein. The 
commitment of poultry creation (meat and eggs) to aggregate livestock yield increased from $26 \%$ in 1995 to $27 \%$ in 1999 with an increased in egg production alone representing about $13 \%$ during the period. The major sources of animal protein in Nigeria are cattle, fish, sheep, goat, pigs and poultry. Poultry production particularly the broiler venture has incredible potentials for expanding protein supply in Nigeria. This is ascribed to the fast growth rates and productivity of the animal.

The Nigerian Agricultural Economy delighted in decade of boom in poultry production between mid-70's and mid 80's. For instance, the population of cattle (174.32 million), goat (156.6 million) and sheep (190.31 million) while that of poultry was evaluated to be 660 million against other animal populace in 1983. It reported that the poultry industry has turned into a diverse business with an assortment of business interest, for example, egg production, broiler production, hatchery and poultry hardware business [12]. The significance of animal protein remains undisputed; animal protein supply man with high quality nourishment which aid growth, development and tissue replacement. It decides the level of nourishment of the populace and the health of the labor forces, which thusly decides the advancement of a country and its economy.

The significance of broiler production in Nigeria cannot be overemphasized as pointed out in the background information. Broiler production plays a very important role in supply of protein for human's consumption. Healthy labor force is as a result of adequate protein intake. In a recent study of the nutrient content of rabbit meat to other farm animals by (FAO), it was found that broiler (chicken) has the most astounding protein content of 21-50 percent contrasted with rabbit and beef, which contain $20-22$ percent and 18 percent protein respectively [22]. Nigeria like most other developing nations is confronted with inadequate supply of animal protein. Over the years, Nigerian government and people have attempted to plan strategies that will encourage broiler production. These were due to the profitability of the business. The point is to meet the developing need of protein (balanced) for a healthy work force and demand for the overflowing populace to act naturally adequate. Today, the decline in the growth of broiler production has proceeded unabatedly. The greatest challenge confronting policy makers in Nigeria is the way to enhance household food consumption. This is in terms of quality and quantity of diet as well as to address the issue of nutritional unevenness of the teeming population of the nation [26].

In spite of the nutritive value of poultry meat; its production in the nation is terribly insufficient as reflected in the wide gap between demand and supply of the product, this could be attributed to various issues that poultry farmers in Nigeria are facing. The main problem of broiler production in Nigeria is that of low productivity which is ascribed to technical inefficiency, high cost of production, inadequate extension services and training facilities [21]. For Nigerian to be able to solve this issue of deficient animal protein; broiler production must be technically efficient and profitable. These problems also include low capital base, inefficient management, economic inefficiency, diseases and parasites and poor housing [9], high cost of feeds, poor quality of day old chicks, poor transportation network, medications and labor seriously affected productivity [31]. The poultry production capacity of farms has to increase rapidly to be able to meet up with the increasing demand, and for this to be achieved, the present level of technical and economic efficiency must be improved upon.

Despite the significance of the broiler industry, there is no study conducted to assess the level of profitability and technical efficiency of this venture in the study area. This necessitates a comprehensive study on the broiler production enterprise in the study area. It is believed that the findings of the study when completed will be useful to investors in the broiler business by identifying problem areas, prospects and potential area of improvement. This study aims at improving the level of protein intake in the study area by making recommendations that will help to counter the effects of problem encountered in broiler production. There were observations that there was poor private sector investment in agricultural production. It will also aim at encouraging private sector investment by revealing the returns or profitability and technical efficiency accruable from broiler production. It is expected that the study will provide an analytical framework for those currently engaged in the business to determine the actual level of their profitability and technical efficiency. It will assist banks particularly credit managers, in determining the credit worthiness of their clients before extending loans. Similarly, the study will prove invaluable to the government of Lagos State, as a basis for rational and empirical policy formulation for broiler production in the state. Finally, at the end of this research, solutions to the existing problems militating against the growth and development of the broiler production to the broiler farmers in Lagos State Poultry Estates, Nigeria will be proffered, and this work will be of assistance to researchers who will identify other areas for further studies of the broiler production enterprises. The main objective of this study is to determine the Profitability and Technical Efficiency of Broiler Production in Lagos State Poultry Estates. The specific objectives are to: describe the socio-economic characteristics of broiler producers the study area; determine the cost and returns associated with broiler production; determine the technical efficiency of broiler production in the study area; identify the problems associated with broiler production in the study area.

\section{Methodology}

\subsection{Study Area Description}

This study was carried out in Lagos State, South-Western geopolitical zone of Nigeria. Lagos State is the most populated State in Nigeria and consists of 20 Local Government Area (LGA) including; Badagry, Ojo, and Ikorodu. The three local governments were chosen as the 
study area being the largest, predominantly agricultural, and rural and the overall second largest LGA in the State [28]. Lagos State Poultry Estate is a sector of livestock production under the auspices of Lagos State Ministry of Agriculture and Cooperative. The poultry estates are located in the 3geopolitical zone of Lagos State which are Ikorodu, Badagry and Ojo. The Erikorodo poultry estate is one of the farm estates in various parts of the state to bring about selfsufficiency in chicken production. The estate is leased out to poultry famers who are expected to build chicken farms where the chicks are raised. The majority of the farmers are small scale farmers. Majority of the inhabitants of the study area are farmers noted for arable crops, vegetable, livestock, fishing, non-fishing activities and poultry production.

\subsection{Sampling Size and Technique}

The respondents were broiler producers; two-stage random sampling method was employed in the research. The first stage involved the purposive selection of the three (3) poultry estates under the Lagos State Ministry of Agriculture and Cooperative which are Erikorodo poultry estate (Ikorodu), Ajara Farm settlement (Badagry) and Aiyedoto poultry estate (Ojo), where poultry production is predominately practiced. The second stage involved simple random selection of 30 out of 73 broiler farmers from Erikorodo poultry estate, 25 out of 30 broiler farmers from Ajara farm settlement and 45 out of 90 broiler farmers from Aiyedoto poultry estate. This was based on the population of the broiler farmers in each of the poultry estate and made the total number of broiler farmers to be 100 out of 193 .

\subsection{Method of Data Collection}

Data for the study was collected from primary sources. This was collected using structured questionnaires complemented with interview schedule. In collecting such data, broiler farmers were asked relevant questions pertaining to broiler production. This includes information from inventories such as receipts, farm records, ledgers, production charts, types and sources of input and production cost as well as returns, also information was obtained on the characteristics of broiler farmers in the study area such as age, sex, marital status, no of household members, farming experience, sources of capital and generally on the economics of broiler production.

\subsection{Analytical Techniques}

The socio-economic characteristics of the broiler producers in the study area and how they affect the profitability of broiler production were described using descriptive statistics such as tables, frequency and percentage distribution.

\subsubsection{Farm Budgetary Technique}

The cost and returns associated with broiler production was carried out to determine the profitability of broiler production. Net farm income and gross margin were used to determine the cost and returns of broiler production in the study area using budgetary technique. A farm budget as the detailed physical and financial plan for the operation of a farm for a certain period [35]. The farm budgetary analysis helps to determine the total cost and total revenue that accrued to the enterprise within a specific production period. The gross margin analysis involves evaluating the efficiency of an individual enterprise (or farm plan) so that comparison can be made between enterprises or different farm plans. Gross margin (GM) is the difference between the gross farm income (GI) and the total variable cost (TVC) that is GM = GI - TVC or Gross margin is defined as Gross Return (GR) minus Total variable cost (TVC).

Budgetary Technique

$$
\begin{gathered}
\mathrm{GM}=\mathrm{GR}-\mathrm{TVC}[35] \\
N F I=G M-T F C
\end{gathered}
$$

Where:

$\mathrm{GM}=$ Gross Margin

$\mathrm{TR}=$ Total Revenue

$\mathrm{TVC}=$ Total Variable Cost

TFC $=$ Total Fixed Cost

Other profitability ratio that was determined from the study includes:

1. Return per naira spent in broiler production $=$ Net farm Income $\div$ Total cost

2. Return per man-day $=$ Net farm income $\div$ Total number of man-days

3. Gross Ratio $=$ Total Expenses $\div$ Gross Income

4. Fixed Ratio $=$ Total Operating Cost $\div$ Gross income

5. Operating Ratio $=$ Total Operating Cost $\div$ Gross income

\subsubsection{Stochastic Frontier Production Function}

The stochastic frontier model was used as the inferential statistics for the analysis of technical efficiency. CobbDouglas stochastic production frontier function was used with inefficiency variables to determine the technical efficiency effects of most important variables to the returns of broiler farms. The technical efficiency of an individual farmer is defined in terms of the ratio of the observed output to the corresponding frontier output given the available technology [20].

Model specification: The production stochastic frontier is specified thus;

$$
\operatorname{InY}=\beta 0+\beta 1 \operatorname{InX} 1+\beta 2 \operatorname{InX} 2+\beta 3 \operatorname{InX} 3+\beta 4 \operatorname{InX} 4(\mathrm{~V} i-\mathrm{Ui})
$$

Where:

$\mathrm{Y}=$ Value of broilers produced per farm $(\mathrm{Kg})$

$\mathrm{X}_{1}=$ Quantity of feeds and feed supplements $(\mathrm{Kg})$
$\mathrm{X}_{2}=$ Expenses on medicines/vaccines (

$\mathrm{X}_{3}=$ Expenses on labor (man days)

$\mathrm{X}_{4}=$ Flock size

$\mathrm{V}_{\mathrm{i}}=$ random error assumed to be independent of $\mathrm{U}_{\mathrm{i}}$, 
identical and normally distributed with zero mean and constant variance $(0, \delta 2 \mathrm{v})$

$\mathrm{U}_{\mathrm{i}}$, = technical inefficiency effects which are assumed to be independent of $\mathrm{Vi} \mathrm{V}$, they are non-negative truncation at zero or half normal distribution with $(\mu, \delta 2 u)$

If $\mathrm{Ui},=0$ no allocative inefficiency occurs, the production lies on the stochastic frontier. If $\mathrm{Ui},>0$, production lies below the frontier and it is inefficient. Technical Inefficiency Model in addition to the general model was defined to estimate the influence of some farmer's socio-economic variables on the technical efficiencies of the farmers.

Model specification for the technical inefficiency is:

$$
\mathrm{L}=\alpha 1+\alpha 1 \mathrm{z} 1+\alpha 2 \mathrm{z} 2+\alpha 3 \mathrm{z} 3+\alpha 4 \mathrm{z} 4+\alpha 5 \mathrm{z} 5+\alpha 6 \mathrm{z} 6+\mathrm{e}
$$

Where;

$\mathrm{L}=$ Technical inefficiency

$\mathrm{Z}_{1}=$ Farmer, age (years)

$\mathrm{Z}_{2}=$ Household size (number)

$Z_{3}=$ Level of education (years)

$Z_{4}=$ Years of Experience (years)

$Z_{5}=$ Gender of the farmer $($ Male $=1$, Female $=2)$

$Z_{6}=$ location of the farm (urban $=1$, rural $\left.=0\right)$

While $a_{0}, a_{1} a_{2} \ldots . a_{6}$ are the parameters to be determined together with the variance parameters.

\subsubsection{Point Likert Scale}

The problems broiler farmers encountered were measured using 3-point Likert scale. Sampled broiler producers were asked to rate the constraints to broiler production on a 3 point numerical rating scale of not serious problem $=3$, serious problem $=2$ and very serious problem $=3$. Respondents were expected to tick how serious a problem is against each constraint area, indicating the constraint area in broiler production.

\section{Result and Discussion}

\subsection{Socio-Economic Characteristics of Broiler Farmers.}

The analysis of socio-economic characteristics of the broiler farmers in the study area are presented in Table 1. Table 1 depicts a male dominance $(73 \%)$ in the broiler production while $27 \%$ of the farmers were females in the study area. The implication of this result is that broiler production is more tasking and energy consuming, thus poultry production in this study area is done mostly by males while the females are probably encumbered with domestic activities which are less energy consuming. This result agrees with various authors that reported male dominance in broiler production. $[4,25]$. It also reveals that the average age of the broiler farmers was 45 years. This implies that broiler production in the area was embarked upon by men and women who were physically strong and mentally alert to face challenges which poultry farming requires. Majority of the broiler farmers were in the age range of (40-49) represented by $31 \%$ which in turn suggests high level of buoyancy for agricultural activities. Youths could be attracted to broiler production because of the profitability and viability of the business [18]. This finding agrees with the findings of [45] who reported a mean age of 44 years for broiler farmers in Nigeria. Table 1 also indicates that majority $(80 \%)$ of the broiler farmers were married, while $15 \%$ were single, $4 \%$ were widows while $1 \%$ were separated. The result agrees with that of [4], who reported $86 \%$ married and $14 \%$ unmarried. This implies that the married household tends to be more involved in broiler production because they have more responsibilities and usually sizeable number of the households tends to render assistance on the farm. It can be deduced that majority of them $(76 \%)$ had tertiary education, while those who had only secondary and primary education were $16 \%$ and $3 \%$ respectively and $4 \%$ had adult education and $1 \%$ of no formal education. This indicates that about $99 \%$ of broiler farmers were literates. Educational level of farm owners is very important in the management of broiler birds and it is known to affect their farming activities. The high literacy level of the respondents would afford them the opportunity to understand and adopt modern farm practices thereby enhancing productivity and profitability. This implies that the level of education attained by a farmer increases his farm, productivity and enhances his capacity to understand and evaluate new production technologies [21]. As expected, most of the farmers were able to adopt better innovation techniques and a managerial farming decision making as well as efficient use of inputs [12]. A total of $81 \%$ of the respondents had between $1-10$ years of experience in broiler production. 10\% had between 11-20 years, 5\% had between 21-30 years and 4\% had between 31 years and above. The mean years of experience was found to be 9 years. This suggests that majority of the broiler farmers in the study were new entrants into the business. It is generally expected that productivity increases with years of experienced [44]. Farmers master the techniques of production and avoid previous mistakes. Experienced broiler farmers are likely to make better decisions to enhance productivity and income, because it is expected that experience in broiler production usually determines the effectiveness of farmers' decision with respect to inputs combinations or resource allocation. Years of farming experience affects the productivity and technical efficiency of broiler production. The longer the years of farming experience, the more the knowledge acquired, the more efficient the farmer is expected to be [21]. The broiler farmers in the study area had a mean flock size of about 400 birds. Majority of the broiler farmers $(68 \%)$ stocked less than 500 birds, 22\% of the broiler farmers stocked between 501-1000 birds while only $7 \%$ and $3 \%$ kept between $1001-1500$ birds and $1501-2000$ birds respectively. The dominant small-scale of most farms are attributed to the high cost required to operate large scale enterprise and inadequate capital faced by the farmers. 
Table 1. Socio-Economic Characteristics of Broiler Farmers.

\begin{tabular}{|c|c|c|c|}
\hline Variables & Frequency & Percentage (\%) & Cumulative\% \\
\hline \multicolumn{4}{|l|}{ Gender } \\
\hline Male & 73 & 73.0 & 73.0 \\
\hline Female & 27 & 27.0 & 100.0 \\
\hline \multicolumn{4}{|l|}{ Age group (years) } \\
\hline $20-29$ & 10 & 10.0 & 10.0 \\
\hline $30-39$ & 24 & 24.0 & 34.0 \\
\hline $40-49$ & 31 & 31.0 & 65.0 \\
\hline $50-59$ & 28 & 28.0 & 93.0 \\
\hline $60-69$ & 7 & 7.0 & 100.0 \\
\hline Mean & 44.7 & & \\
\hline \multicolumn{4}{|l|}{ Level of Involvement } \\
\hline Full time & 90 & 90.0 & 90.0 \\
\hline Part time & 10 & 10.0 & 100.0 \\
\hline \multicolumn{4}{|l|}{ Marital status } \\
\hline Single & 15 & 15.0 & 15.0 \\
\hline Married & 80 & 80.0 & 95.0 \\
\hline Widow & 4 & 4.0 & 99.0 \\
\hline Separated & 1 & 1.0 & 100 \\
\hline \multicolumn{4}{|l|}{ Educational Level } \\
\hline No formal education & 1 & 1.0 & 1.0 \\
\hline Primary education & 3 & 3.0 & 4.0 \\
\hline Secondary education & 16 & 16.0 & 20.0 \\
\hline Tertiary education & 76 & 76.0 & 96.0 \\
\hline Adult education & 4 & 4.0 & 100.0 \\
\hline \multicolumn{4}{|l|}{ Years of Experience } \\
\hline $1-10$ & 81 & 81.0 & 81.0 \\
\hline $11-20$ & 10 & 10.0 & 91.0 \\
\hline $21-30$ & 5 & 5.0 & 96.0 \\
\hline 30 and above & 4 & 4.0 & 100 \\
\hline Mean & 8.47 & & \\
\hline \multicolumn{4}{|l|}{ Household size } \\
\hline $1-5$ & 78 & 78.0 & 78.0 \\
\hline $6-10$ & 19 & 19.0 & 97.0 \\
\hline $11-15$ & 3 & 3.0 & 100.0 \\
\hline Mean & 4.28 & & \\
\hline \multicolumn{4}{|l|}{ Flock Size } \\
\hline $20-500$ & 68 & 68.0 & 68.0 \\
\hline $501-1000$ & 22 & 22.0 & 90.0 \\
\hline $1001-1500$ & 7 & 7.0 & 97.0 \\
\hline $1501-2000$ & 3 & 3.0 & 100.0 \\
\hline Mean & 379.86 & & \\
\hline Total & 100 & 100 & \\
\hline
\end{tabular}

\subsection{Cost, Returns and Profitability of Broiler Production in the Study Area}

Costs can be defined as the value of inputs used in production or expenses incurred in producing an amount of the product, while return is the profit made at the end of production. The net farm income is defined as the gross farm income less gross farm costs and serves as a factor for measuring profitability [41]. The costs, returns and profitability of broiler production are presented in table 2. It was found that $\$ 469,526.45$ which is $81.85 \%$ of the average total cost of production was on the variable inputs. Feeds constituted the highest percentage of the variable costs, accounting for $54.86 \%$ and $44.8 \%$ of the total cost. This agrees with the findings of [26] that feeding poultry birds accounted for over $50 \%$ of the total cost of production. Also, the table reveals that the cost of buying the day-old chicks (flock) represented $16.35 \%$ of the production cost. This agrees with [34] that any management intervention towards cutting down the cost of production in any poultry enterprise will need to lay emphasis on cost of stock and feed. This is followed by cost of labour $(16.26 \%)$, cost of power $(5.83 \%)$, and cost of medication $(3.99 \%)$ while transportation and other costs constituted the least. The straight-line method of depreciation was used to determine the cost of fixed inputs which was $\mathrm{N} 104,192.22$. This is the mean total depreciation for the 100 broiler farmers which is $18.15 \%$ of the average total cost of production in the study area.

\subsection{Budgetary Analysis of Broiler Farmers in the Study Area}

Table 3 shows the budgetary analysis of the broiler farms, results show that broiler production is a profitable venture in the study area (though producing at small-scale level). The result of the survey showed that a single broiler bird nurtured to maturity had a total cost of $\$ 1509.8$ made up of $\$ 274.19$ fixed cost estimated and 1235.60 variable cost, with gross revenue per bird at $\$ 2169.99$. Net profit of $\$ 660.11$ per bird was estimated and this gives a net margin-to-cost ratio of 0.44 which implies that a 1 investment in broiler production, all things being equal, would yield 44 kobo in return.

Source: Field survey, 2016.

Table 2. Cost Percentage Distribution for the broiler farmers in the study area.

\begin{tabular}{llll}
\hline Item & Mean amount ( $)$ & \% of Variable Cost/Fixed Cost & \% of Total cost \\
\hline Total revenue & $133,935,700$ & & \\
Variable Cost & & & $13.94 \%$ \\
Cost of Day-old chicks & $76,830.00$ & $16.35 \%$ & $3.24 \%$ \\
Cost of Medication & $18,749.40$ & $3.99 \%$ & $1.62 \%$ \\
Cost of Transportation & $9,461.00$ & $2.01 \%$ & $13.28 \%$ \\
Cost of Labour & $76,385.00$ & $16.26 \%$ & $0.51 \%$ \\
Cost of Litter & $3,043.80$ & $0.70 \%$ & $44.80 \%$ \\
Cost of Feed & $257,625.00$ & $54.86 \%$ & $4.75 \%$ \\
Cost of power & $27,432.25$ & $5.83 \%$ & $81.85 \%$ \\
Total variable cost & $469,526.45$ & $100 \%$ & \\
\hline
\end{tabular}




\begin{tabular}{llll}
\hline Item & Mean amount (\#) & \% of Variable Cost/Fixed Cost & \% of Total cost \\
\hline Fixed Cost & & & $12.05 \%$ \\
Depreciation on Broiler house & $69,025.00$ & $66.26 \%$ & $0.65 \%$ \\
Feeders and Drinkers Depreciation & $2,032.82$ & $3.98 \%$ & $1.87 \%$ \\
Depreciation on Heat \& power supply & $10,611.80$ & $10.22 \%$ & $0.20 \%$ \\
Depreciation on farm tools & 368.50 & $1.38 \%$ & $3.38 \%$ \\
Depreciation on Tank and Borehole & $18,837.60$ & $18.16 \%$ & $18.15 \%$ \\
Total fixed cost & $104,192.22$ & $100 \%$ & $100 \%$ \\
Total cost of production & $573,718.67$ & $100 \%$ & \\
Mean net revenue & $869,357.00$ & & \\
\hline
\end{tabular}

Source: Authors' computation.

Table 3. Cost and return analysis of broiler farmers.

\begin{tabular}{ll}
\hline Revenue & \\
\hline Revenue & Value (\$) \\
\hline Total Broiler sale & 82456100 \\
Gross Revenue $(G R)$ & $=82,456,100$ (100 farmers) \\
\hline
\end{tabular}

Table 3. Continued.

\begin{tabular}{|c|c|}
\hline \multicolumn{2}{|l|}{ Cost } \\
\hline Variable Cost & Value (\#) \\
\hline Cost of Day-old chicks & $7,683,000$ \\
\hline Cost of Medication & $1,874,940$ \\
\hline Cost of Transportation & 946,100 \\
\hline Cost of Labour & $7,638,500$ \\
\hline Cost of Wood shavings & 304,380 \\
\hline Cost of Feed & $25,762,500$ \\
\hline Cost of power & $2,743,225$ \\
\hline Total Variable Cost (TVC) & $=\# 46,952,645$ \\
\hline Gross Margin (GR-TVC) & $\begin{array}{l}=\circledast 82,456,100-46,952,645 \\
=® 35,503,455 \text { (100 farmers) }\end{array}$ \\
\hline Fixed Cost & (\#) \\
\hline Depreciation on Broiler house & $6,902,500$ \\
\hline Feeders and Drinkers Depreciation & $6,902,500$ \\
\hline Feeders and Drinkers Depreciation & 203,282 \\
\hline Depreciation on Heat \& power supply & $1,061,180$ \\
\hline Depreciation on farm tools & 36,850 \\
\hline Depreciation on Tank and Borehole & $1,883,760$ \\
\hline Total fixed cost & $10,419,222$ (100 farmers) \\
\hline Total Cost $(T C=T V C+T F C)$ & $=\mathrm{N} 57,371,867$ \\
\hline Net Farm Income (GM-TFC) & $\begin{array}{l}=35,503,455-10,419,222 \\
=\$ 25,084,233\end{array}$ \\
\hline Average Gross Margin & $=\mathrm{N} 355,034.55$ per farmer \\
\hline Average Net Farm Income & $=\mathrm{N} 250,842.33$ per farmer \\
\hline Gross margin per bird & 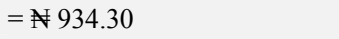 \\
\hline Net farm income per bird & $=\mathrm{N} 660.11$ \\
\hline
\end{tabular}

Source: Field survey, 2016.

\subsubsection{Profitability Ratios for Broiler Production}

From the table above:

Average Variable Cost $=469,526.45$ per farmer

Average Fixed Cost $=104,192.22$ per farmer

Average Total cost $=\$ 573,718.67$ per farmer

a. Total Variable Cost per Bird =

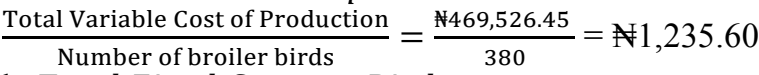

b. Total Fixed Cost per Bird $=$

$\frac{\text { Total Fixed Cost of Production }}{\text { Number of broiler birds }}=\frac{\$ 104,192.22}{380}=\$ 274.19$

c. Total Cost per bird $=\$ 1235.59+\$ 274.19=$

\#1509.79 per bird

\subsubsection{Other Profitability Ratios}

Other profitability ratio that was determined from the study includes:

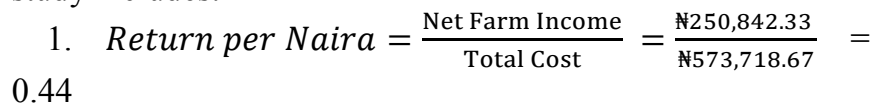

This ratio of 0.44 simply means that, for every one naira invested into broiler production, forty-four kobo would be return, all things being equal.

$$
\text { 2. Return per Mandays }=\frac{\text { Net Farm Income }}{\text { Total mandays }}=\frac{\aleph 250,842.33}{7,996}
$$
$=31.37$

3. Gross Ratio $=\frac{\text { Total Cost }}{\text { Gross Income }}=\frac{\$ 573,718.67}{\$ 869,357.00}=0.66$

This ratio shows that the total farm costs was about $66 \%$ of the gross income. This measure the overall financial success of broiler production.

4. Fixed Ratio $=\frac{\text { Total Fixed Income }}{\text { Gross Income }}=\frac{\$ 104,192.22 .45}{\$ 869,357.00}=0.12$

$12 \%$ of the gross income is being used for fixed cost of production.

5. Operating Ratio $=\frac{\text { Total Variable Cost }}{\text { Gross Income }}=\frac{\$ 469,526.45}{\$ 869,357.00}$

This ratio shows that $54 \%$ of the gross income is used to pay for the operating (variable) costs.

\subsection{Technical Efficiency Analysis}

\subsubsection{Maximum Likelihood Estimates of Parameters of the Stochastic Frontier Production}

Table 4 shows The Maximum Likelihood Estimates (MLE) of the stochastic frontier production parameters for broiler production in the study area. The table shows that of the four production factors, quantity of feed and flock size were highly significant at $5.0 \%$ and $1.0 \%$ risk level respectively and this indicating they have high influence on the value of output of broilers. The positive and significant relationship between quantity of feed and broiler output indicates that if there is 5 percent increase in feeds given to the broilers, there will be 2.27 percent increase in the output of broiler production. This indicates that the higher the feed intake by the birds, the greater the technical efficiency of the farmers. The estimated coefficient for flock size is positive (4.117) and implies that every one percent increase in flock size, would lead to 4.12 percent increase in the value of broilers produced. This implies that broilers production increased with 
increase in number of birds this agrees with $[20 \& 4]$ and that the larger the flock size, the less inefficient a farmer becomes. The insignificant outcome for the cost of medication is surprising and the non-significance of the cost of labour is expected as most of the broiler farmers employed the use of family members which is not costed.

Table 4. Estimated Stochastic Frontier Production Function (MLE) for Broiler production.

\begin{tabular}{|c|c|c|c|c|}
\hline Variable & Parameter & Coefficient & Standard error & T-ratio \\
\hline Constant & $\beta_{0}$ & 7.443 & 0.396 & $18.804 * * *$ \\
\hline Quantity of feed & $\beta_{1}$ & 2.508 & 1.105 & $2.269 * *$ \\
\hline Expenses on medication & $\beta_{2}$ & 0.649 & 1.939 & 0.335 \\
\hline Expenses on labor & $\beta_{3}$ & 2.755 & 2.512 & 1.096 \\
\hline Flock size & $\beta_{4}$ & 10.708 & 2.601 & $4.117 * * *$ \\
\hline
\end{tabular}

Note $* * * \mathrm{~T}$ - value significant at $1 \%$ and $* * \mathrm{~T}$ - value significant at $5 \%$

Source: Authors' computation from field survey, 2016

\subsubsection{Factors Influencing Technical Efficiency of Broiler Production}

The determinants of technical efficiency in broiler production are presented in Table 5. The result of the analysis shows that educational level of farmers and farmers experience, were statistically significant at varied risk levels. However, age, family size, gender and location of farm were found to be insignificant coefficients. This implies that these factors do not contribute to farm inefficiency. Since these variables were not significant, they do not deserve further discussion. The positive sign obtained for level of education and $5 \%$ significant relationship conformed to a priori expectation and was similar to the findings of [4]. The implication of this is that the higher the level of education, the less inefficiency the broiler farmers will be. The reason may be due to proper application of education which increases the rate of innovation adoption. The more educated the farmer becomes the more equipped he is to make the best of the technology available to him for increased technical efficiency [25]. Level of education has been shown to improve the productivity of the farmers [21]. Level of education is related to the efficient management of broiler farms such as light enclosure, vaccination, medication and feeding can bring about significant improvement in productivity of broiler production [1]. The year of experience is positively signed and highly significant at $1 \%$ level of probability which implies that farmers with more years of experience tend to be more technically efficient in broiler production. Continuous practice of an occupation for a long period presumably makes a person more experienced and more productive in practice. This agreed with [44], who reported that years of experience reduce farmers inefficiency. The total variance $\left(6^{2}\right)$ is 6.755 while the variance ratio $(Y)$ is 0.655 . Variance of the farm specific technical efficiency to the total variance is measured to be variance ratio. This means that $99.35 \%$ of the variations in output among the broiler farmers were due to the inconsistencies in technical efficiency. The total variance of 6.755 is statistically significant and as such, indicates a goodness of fit and the correction of the specified hypothesis of the composite error term distribution. Estimated technical efficiency of the broiler farmers ranged from $57.88 \%$ to $96.31 \%$ with a mean technical efficiency of $74.74 \%$. The variation in the level of technical efficiency indicates that more opportunities exist for broiler farmers to increase their broiler productivity and income by $25.26 \%$ through improvements in their technical efficiency of production.

The null hypothesis of no inefficiency effects in broiler production $\gamma=0$, was strongly rejected.

Table 5. Sources of Technical Efficiency in Broiler Production.

\begin{tabular}{llll}
\hline Variable & Parameter & Coefficient & Standard Error \\
\hline Constant & $Z_{0}$ & 0.241 & 0.275 \\
Age & $Z_{1}$ & 3.949 & 2.717 \\
Household size & $Z_{2}$ & -1.229 & 1.142 \\
Level of education & $Z_{3}$ & 1.005 & 0.392 \\
Years of experience & $Z_{4}$ & -1.341 & 0.273 \\
Gender & $Z_{5}$ & 0.307 & 0.501 \\
Location of farm & $\mathrm{Z}_{6}$ & -1.348 & 4.090 \\
Diagnostic statistics & & & 0.575 \\
Total variance & $6^{2}$ & 3.456 & 0.572 \\
Variance ratio & $\mathrm{Y}$ & 0.233 & 0.356 \\
L R Test & & 14.130 & 0.665 \\
Log likehood function & & 26.667 & -0.329 \\
Mean Technical efficiency & & 0.7474 & $0.755^{* * *}$ \\
Number of observation & & 100 & 0.655 \\
\hline
\end{tabular}

Note $* * *$ T- value significant at $1 \%$ and $* *$ T- value significant at $5 \%$

Source: Authors' computation from field survey, 2016. 


\subsection{Constraint of Broiler Production in the Study Area}

The result of the analysis presented in table 6 revealed the constraints to broiler production in declining order of importance in terms of severity of the challenges. It reveals that disease outbreak, inadequate finance, and high cost of feed were the factors affecting the productivity of the broiler farmers while disease outbreak is valued highest in the list above with a mean score of 2.43 on the likert type scale, this implies that the lesser the problem of disease outbreak for broiler production the more or higher the level of output (all things being equal).

\subsubsection{Disease Outbreak}

The broiler farmers rated disease outbreaks as the most serious problem affecting broiler production in the study area. Disease outbreaks such as bird flu, Newcastle, gumboro, marek, fowl pox diseases etc tends to increase the cost of medication which directly increases the operating cost and this problem increases the mortality rate causing a decrease in the profit generated from broiler production. This is probably because most of small scale broiler farmers could not identify the symptoms of disease earlier enough to prevent disease outbreak which is a major threat that wipe out many of the broilers in developing countries. This supported the assertion of [13].

\subsubsection{Inadequate Finance}

This was the next most serious constraints identified by the respondents. Inadequate finance could be the reason why farmers could not acquire the necessary inputs especially fixed inputs for large scale production which attracts higher profit and efficiency. Supporting this assertion, [44], in his work found that Technical Efficiency was highly influenced by financial constraints. This is because in addition to the quantity of inputs used, the timing of input usage also affects farm output.

\subsubsection{High Cost of Feed}

This was the next most serious constraints identified by the respondents. High cost of feed such as broiler starter and finisher caused by the general inflation in the Nigeria economy and high value of exchange rate between the foreign countries which supply the raw materials for feed formulation. This makes it very difficult for existing farms to expand their scale of operation making a large number of them to stagnate in the small-scale class, while new ones are reluctant to go into the business. This is in agreement with [5, 41].

\subsubsection{Other Problems}

Other bottlenecks affecting broiler production in the study area as identified by the respondents includes the following in order of severity; Inadequate Market, inefficient extension services, lack of storage facilities, pests and diseases, low manpower, poor infrastructure, feed scarcity and poor quality of day old chicks were of minor problems to the Broiler industry in the study area.

Table 6. Constraints facing broiler farmers in the study area.

\begin{tabular}{|c|c|c|c|c|c|c|c|}
\hline Constraints & Not serious (1) & Serious (2) & Very serious (3) & Total & Mean Score & Rank & Decision \\
\hline Inadequate Finance & 16 & 31 & 53 & 100 & 2.37 & 2 & Serious \\
\hline High cost of feed & 8 & 58 & 34 & 100 & 2.26 & 3 & Serious \\
\hline Disease outbreak & 10 & 37 & 53 & 100 & 2.43 & 1 & Serious \\
\hline Theft & 59 & 36 & 4 & 100 & 1.44 & 13 & not serious \\
\hline Pest and Disease & 33 & 62 & 5 & 100 & 1.72 & 8 & not serious \\
\hline Low Manpower & 44 & 47 & 9 & 100 & 1.65 & 9 & not serious \\
\hline Poor infrastructure & 49 & 48 & 3 & 100 & 1.54 & 10 & not serious \\
\hline Feed scarcity & 54 & 40 & 6 & 100 & 1.52 & 11 & not serious \\
\hline Inefficient extension service & 41 & 39 & 20 & 100 & 1.79 & 5 & not serious \\
\hline Lack of storage facilities & 43 & 41 & 16 & 100 & 1.73 & 7 & not serious \\
\hline Poor quality of day old chicks & 63 & 28 & 9 & 100 & 1.46 & 12 & not serious \\
\hline
\end{tabular}

Source: field survey, 2016.

\section{Conclusion}

Based on the findings, it can be deduced that broiler production is a profitable venture with an average gross margin of 355,034.55 kobo and an average net income of 250,842.33kobo per farmer in a production cycle. It was deduced that the educational level and farming experience of the broiler farmers are the major determinants of technical efficiency. The implication of the study therefore is that the level of Technical efficiency among broiler farmers in the poultry estates could be improved by $26 \%$ through better utilization of available resources. It was also concluded that the major bottlenecks affecting the broiler producers in the poultry estate in order of severity are that of disease outbreak, inadequate finance and high cost of feed.

\section{Recommendations}

From the findings, it should be recommended that;

1. Broiler farmers should be encouraged to increase their scale (flock size) of production for increased 
profitability.

2. Broiler farmers should be encouraged to keep record of their sales, purchase and debts in order to determine the performance of the farm and for effective management decisions.

3. Stakeholders in the poultry estate should motivate extension agents through provision of incentives such as; trainings, scholarship and better salaries. This will enhance the efficiency of the extension service which will also affects improved method of broiler production.

4. Modern feed mill which will make use of local materials in the poultry estates should be provided, so as to provide feeds to broiler farmers at reduced price and broiler farmers should develop the skill of feed formulation.

5. Effective and efficient vaccination programme in broiler production should be encouraged to minimize mortality and losses from many dreadful poultry diseases such as mareks, newcatle etc.

\section{References}

[1] Aboki E. 1, Jongur A. U and Onu J. I (2013). "Productivity and Technical Efficiency of Family Poultry Production in Kurmi local Government Area of Taraba State, Nigeria". Journal of Agriculture and Sustainability Volume 4, Number $1,52-66$.

[2] Adebayo, C. O., Oseghale, A. I. and Adewumi, A. A (2015). "Profitability and Technical Efficiency Among Broiler Farmers in Kwara State, Nigeria". Nigerian Journal of Agriculture, Food and Environment. 11 (2):92-96.

[3] Adepoju A. A. 2008. "Technical Efficiency of Egg Production in Osun State". International Journal of Agricultural Economics and Rural Development 1:1-8.

[4] Adesiyan, Olusegun Israel (2014). "Technical Efficiency of Poultry Production in Afijio Local Government Area of Oyo state, Nigeria". Developing Country Studies (www.iiste.org) Vol. 4, No. 20.

[5] Afolami C. A., Aladejebi O. J., Okojie L. O (2013). “Analysis of Profitability and Constraints in Poultry Egg Farming Under Battery Cage and Deep Litter Systems in Ogun State, Nigeria: A Comparative Study. IJAFS 4, 20: 581- 595.

[6] Ahmed Abdallah and Ahmad Al Khraisat (2013). "Economic Analysis of Poultry (Broiler) Production in Amman and Irbid District in Jordan". International Journal of Life Sciences Research (IJLSR) Vol. 1, Issue 1, pp: (24-30).

[7] Aigner, D. J, C. A. K. Lovell and P. Schmidt (1977) "Formulation and Estimation of Stochastic Frontier Function models" Journal of Economics 1 (1): 21-37.

[8] Akpabio, 1. A., Okon, D. P., Angba, A. O. and Aboh, C. L (2007). "Avian Influence Scare and the Poultry Egg Production in Uyo Urban, Nigerian". International Journal Poultry Science 6: 298-301.

[9] Alabi, R. A. and Aruna, M. B. (2006). "Technical Efficiency of Family Poultry Production in Niger-Delta, Nigeria".
Journal of Central European Agriculture,. 6 (4):531-538.

[10] Alamu, J. F. and Olukosi, J. O. (2010), "Simplified Research Methodology: Principles and practice". Department of Agricultural and Rural Sociology, Ahmadu Bello University, Zaria.

[11] Alrwis K. N. and Franscis E. (2010). "Technical Efficiency of Broiler Farms in the Central Region of Saudi Arabia: Stochastic Frontier Approach.

[12] Amos T. T. (2006) "Analysis of Backyard Poultry Production in Ondo State, Nigeria". International Journal of Poultry Science 5 (3): 247-250.

[13] Aromolaran A. K., Ademiluyi I. O. and Itebu O. Jennifer (2013). "Challenges of Small Poultry Farms in Layer Production in Ibadan Oyo State Nigeria". Global Journal of Science Frontier Research Agriculture and Veterinary Sciences, Volume 13 Issue 2 Version 1.0.

[14] Babalola, D. A and Y. Babalola (2013). "Economic Effects of Media Campaign against Pandemic Diseases: The Case of Bird Flu (H5N1) on Poultry Business in Ogun State, Nigeria". Arabian Journal of Business and Management Review 2 (12):80-88.

[15] Bamiro O. M., Otunaiya A. O, and Adejumo I (2013). "Profit Efficiency in Poultry Production in Peri-Urban Lagos, Nigeria". International Journal of Applied Agriculture and Apiculture Research. Vol 9, No 1-2.

[16] Binuomote, S. O., Ajetomobi, J. O. and Ajao, A. O. (2008). "Technical Efficiency of Poultry Egg Producers in Oyo State, Nigeria." International Journal of Poultry Science, 7 (12):1227-1231.

[17] Central Bank of Nigeria, (2007), Annual Report and Statements of Accounts.

[18] Chukwu, J. A. (2007) "Technical Efficiency of Broiler Production in Umuahia North and Umuahia South L. G. As Abia State, Nigeria". B. Agric. Thesis. Dept. of Agric. Economics and Extension, Abia State University, Uturu.

[19] Debreu, G. (1951). "The Coefficient of Resource Utilization" Dans Econometrics, pp: 273-292.

[20] Effiong, E. O., and Onyenweaku, C. E. 2006. "Profit Efficiency in Broiler Production in Akwa Ibom State, Nigeria". Global Journal of Agricultural Sciences, 5 (1): 4347.

[21] Ezeh C. I., Anyiro C. O. and Chukwu J. A (2012). "Technical Efficiency in Poultry Broiler Production in Umuahia Capital Territory of Abia State, Nigeria" Greener Journal of Agricultural Sciences ISSN: 2276-7770 Vol. 2 (1), pp. 001007.

[22] FAO, (2008), Poultry in the 21 century: Avian Influenza and beyond. Proceedings of the International Poultry Conference, November 5-7, 2007, Bangkok, Thailand.

[23] Farrel, M. J. (1957). "The Measurement of Productive Efficiency”. Journal Royal State, Social, Series A, 120:253281.

[24] Ike P. C (2011). "Resource Use and Technical Efficiency of Small Scale Poultry Farmers in Enugu State, Nigeria: A Stochastic Frontier Analysis". International Journal of Poultry Science 10 (11): 895-898. 
[25] Ike P. C. and Ugwumba C. O. A (2011). "Profitability of Small Scale Broiler Production in Onitsha North Local Government Area of Anambra State, Nigeria”. International Journal of Poultry Science 10 (2): 106-109.

[26] Kalla D. J. U., Barrier G., Haruna U., Abubakar M., Hamidu B. M., and Murtala N (2007). "Economic Analysis of Broiler Production at Miango Plateau State, Nigeria". Paper prepared for presentation at the Farm Management Association of Nigeria Conference, Ayetoro, Nigeria.

[27] Kumbhakar, S. C., S. Ghosh, and J. T. McGuckin (1991). A Generalized Production Frontier Approach for Estimating Determinants of Inefficiency in U.S. Dairy Farms. Journal of Business and Economic Statistics 9:279-286.

[28] Lagos State Business Directory (2012). Information Supplied by Lagos State Ministry of Commerce and Industry. LSBD, Ikeja, Lagos State. www.lagosstate.gov.ng.

[29] Mbanasor, J. A., (2000). "The future of livestock industry in Nigeria". A paper Presented at the $25^{\text {th }}$ annual conference of NSAP 19th to 23rd March 2002. Umudike, Nigeria.

[30] Meeusen, W. And Van Den Broeck, J. (1977). "Estimation from Cob-Douglas Production Functions with Composed Error": Econometrics, 18:435-444.

[31] Mgbakor M. N and Nzeadachie E. C (2013). "Economic Analysis of Broiler Production: A Case Study of Orumba South L. G. A of Anambra State, Nigeria". AmericanEurasian Journal of Agronomy 6 (2): 25-31, 201.

[32] Ohajianya D. O., Mgbada J. U., Onu P. N., Enyia C. O., Henri-Ukoha A., N. Ben-Chendo G. and Godson-Ibeji C. C (2013). "Technical and Economic Efficiencies in Poultry Production in Imo State, Nigeria". American Journal of Experimental Agriculture 3 (4): 927-938.

[33] Ojo, S. O. (2003). "Productivity and Technical Efficiency of Poultry Egg Production in Nigeria": Internal Journal of Poultry Science 2 (6):459-464.

[34] Oladunni, M. E. 1 \& Fatuase, A. I. (2014). "Economic Analysis of Backyard Poultry Farming in Akoko North West Local Government Area of Ondo State, Nigeria" Global Journal of Biology, Agriculture and Health Services Vol. 3 (1):141-147.

[35] Olukosi, J. O. and Erhabor, P. O. (1988). "Introduction to Farm Management: Principles and Applications". AGITAB Publishers Ltd, Zaria, Nigeria.

[36] Otunaiya A. O, Adeyonu A. G, and Bamiro O. M (2015). "Technical Efficiency of Poultry Egg Production in Ibadan
Metropolis, Oyo State, Nigeria. Economics. Vol. 4, No. 3, pp. $50-56$

[37] Philip D., Nkonya E., Pender J. and Oni O. A. (2009). "Constraint to Increasing Agricultural Productivity in Nigeria: A review, Nigeria Strategy Support Program (NSSP) Background Paper No. 6.

[38] Sanni, S. A. and Ogundipe, S. O. (2005). "Economics of some modules of poultry production in Kaduna State, Nigeria". Nigerian Journal of Animal Production, 32 (1): 102-107.

[39] Tanko L. and Okonkwo N. (2005). "Technical Efficiency of Small-Scale Broiler Production in the Federal Capital Territory, Abuja, Nigeria: Data Envelopement Analysis Approach". International Research Journal of Agricultural and Aquatic sciences.

[40] Taru V. B., Nkwi G. E., Medugu A. I. and Reuben J (2010). "Economics of Broiler Production in Meme Division of Cameroon”. Journal Agricultural Sciences, 1 (2): 83-87.

[41] Tijjani H., Tijani B. A., Tijjani A. N. and Sadiq M. A (2012). "Economic analysis of poultry egg production in Maiduguri and environs of Borno State, Nigeria". Scholarly Journal of Agricultural Science Vol. 2 (12), pp. 319-324.

[42] Todsadee A., Kameyama H., Ngamsomsuk K., Yamauchi K. (2012) "Technical Efficiency of Broiler Farms in Thailand: Data Envelopment Analysis (DEA) Approach". British Journal of Economics, Finance and Management Sciences. Vol. 5 (1).

[43] Udoh, E. J. and Etim, N. A. 2009. "Measurement of Farm Level Efficiency of Broiler Production in Uyo, Akwa Ibom State, Nigeria". World Journal of Agricultural Sciences 5 (5):823-836.

[44] Umar, M. (November, 2013). "Economic Analysis of PoultryEgg Production in Bauchi Local Government Area, Bauchi State, Nigeria". Published M.Sc. Dissertation Thesis Department Of Agricultural Economics and Rural Sociology, Faculty of Agriculture, Ahmadu Bello University, Zaria, Nigeria.

[45] Yusuf, S. A. and Malamo, O. (2007). "Technical Efficiency of Poultry Egg Production in Osun State: A Data Envelopment Analysis (DEA) Approach. International Journal of Poultry Science 6 (9):622-629.

[46] Zakariya'u, L. (May, 1998). "Economic Analysis Of Broiler Production in Three States of Nigeria". Published M.Sc. Dissertation Thesis Department Of Agricultural Economics and Rural Sociology, Faculty of Agriculture, Ahmadu Bello University, Zaria, Nigeria. 